\title{
DEVELOPMENT OF HEARING IN INFANTS FROM NICU AND INTERMEDIATE CARE WARDS IN BRAZIL
}

Contributions:

A Study design/planning

B Data collection/entry

C Data analysis/statistic

D Data interpretation

E Preparation of manuscript

$\mathrm{F}$ Literature analysis/search

G Funds collection

\section{Karolina Pessote Sideri ${ }^{1 \mathrm{ABD}}$, Thais Antonelli Diniz Hein ${ }^{1 \mathrm{ABDEF}}$, Tatiana Buratto Bordin ${ }^{2 \mathrm{CDE}}$, Maria Francisca Colella-Santos ${ }^{3 \mathrm{ABDEF}}$}

${ }^{1}$ Child and Adolescent Health Program, School of Medical Sciences, University of

Campinas, Campinas, Sao Paulo, Brazil

${ }^{2}$ Eldorado Research Institute, Campinas, Sao Paulo, Brazil

${ }^{3}$ Human Development and Rehabilitation Department, Child and Adolescent Health Program, School of Medical Sciences, University of Campinas, Campinas, Sao Paulo, Brazil

Corresponding author: Karolina Pessote Sideri, Child and Adolescent Health Program, School of Medical Sciences, University of Campinas, Campinas, Sao Paulo, Brazil, e-mail: karolina.sideri91@gmail.com

\section{Abstract \\ Background: Unidentified hearing loss at birth can badly affect the linguistic, social, and educational development of children. National and in- ternational committees on infant hearing emphasize the importance of early identification of hearing loss, with follow-up and early intervention. The aim of this study was to analyze data on hearing development from a program following up exits from the Neonatal Intensive Care Unit (NICU) and from neonatal intermediate care wards in Prof. Dr. Jose Aristodemo Pinotti Women's Hospital in the Brazilian State of Sao Paulo. \\ Material and methods: This was a retrospective study based on records from a follow-up program. Data came from records collected from 2012 to 2015 on 88 subjects, and included the results of behavioral hearing tests, visual reinforcement audiometry and tympanometry. The data were descriptively and statistically analyzed. \\ Results: Changes in the development of hearing abilities over the first two years of life in children that stayed at the NICU or the intermedi- ate care ward for more than 48 hours were significant. However, late-onset or progressive hearing losses were not observed. There was no cor- relation between hearing development and specific risk indicators or with tympanometry. \\ Conclusions: For the analyzed program, progressive or late-onset losses were not found, but there were major delays in the development of hearing abilities in the first two years of life for children from NICU and neonatal intermediate care wards. \\ Key words: audiology $\bullet$ neonatal screening $\bullet$ child development \\ DESARROLLO DE LA AUDICIÓN EN NIÑOS INTERNADOS EN LAS UNIDADES DE CUIDADOS INTENSIVOS Y DE ASISTENCIA SANITARIA INDIRECTA EN BRASIL}

\section{Resumen}

Introducción: Una hipoacusia no diagnosticada después del nacimiento puede tener un impacto negativo en el desarrollo del lenguaje, como también en el desarrollo social y educativo del niño. Las comisiones estatales e internacionales que se dedican a la audición de los neonatos subrayan la importancia de la detección precoz de la hipoacusia, su tratamiento y una intervención temprana. El objetivo de la investigación fue el análisis de los datos relativos al desarrollo de la audición sobre la base del alta hospitalaria de la unidad de cuidados intensivos neonatales (NICU) y de las unidades de asistencia sanitaria indirecta del hospital para mujeres Prof. Dr José Aristodemo Pinotti en el estado brasileño de Sao Paulo.

Material y métodos: Es un estudio retrospectivo basado en la documentación abarcada por el programa de investigación. Los datos proceden de la documentación recopilada desde 2012 hasta 2015, que abarca a 88 pacientes. Contienen los resultados de las pruebas de audición, audiometría VRA (Visual Reinforcement Audiometry) y timpanometría. Los datos fueron sometidos a un análisis descriptivo y estadístico.

Resultados: Los cambios en el desarrollo de las capacidades auditivas durante los primeros dos años de la vida en caso de niños internados en las unidades de cuidados intensivos (NICU) y de asistencia sanitaria intermedia durante más de 48 horas resultaron importantes. Sin embargo, no se observó una aparición tardía o progresiva de la hipoacusia. No existe relación alguna entre el desarrollo de la audición y los síntomas particulares de riesgo o la timpanometría.

Conclusiones: Durante el programa analizado, no se observó la hipoacusia progresiva ni la aparición tardía de la misma, sin embargo, se observaron considerables retrasos en el desarrollo de las capacidades auditivas durante los primeros dos años de vida de los niños internados en las unidades de cuidados intensivos y de asistencia sanitaria indirecta neonatales.

Palabras clave: audiología • cribado neonatal • desarrollo del niño 


\title{
РАЗВИТИЕ СЛУХА У ДЕТЕЙ ИЗ ОТДЕЛОВ ИНТЕНСИВНОЙ ТЕРАПИИ И ПРОМЕЖУТОЧНОГО МЕДИЦИНСКОГО УХОДА В БРАЗИЛИИ
}

\begin{abstract}
Изложение
Введение: Недиагностированная тугоухость после рождения может отрицательно повлиять на языковое, социальное и образовательное развитие ребёнка. Государственные и международные комиссии, занимающиеся слухом новорождённых, подчёркивают значение раннего обнаружения тугоухости, её лечения и ранней реакции. Целью исследования был анализ данных, касающихся развития слуха, на основании выписок из отделений интенсивной терапии для новорождённых (NICU) и отделений промежуточного медицинского ухода в больнице для женщин им. проф. Доктора Жозе Аристодемо Пинотти в бразилийском штате Сан-Паулу.
\end{abstract}

Материал и методы: Это ретроспективное исследование, опирающееся на документации, входящей в иссследовательскую программу. Данные были получены из документации, собранной с 2012 по 2015 год и касающейся 88 пациентов. Они включают данные бихевиоральных исследований слуха, аудиометрии VRA (Visual Reinforcement Audiometry) и тимпанометрии. Данные были подвергнуты описательному и статистическому анализу. Результаты: Изменения в развитии слуховых умений в первые два года жизни у детей, находящихся в отделениях интенсивной терапии (NICU) и промежуточного медицинского ухода в течение более чем 48 часов, были существенными. Однако не обнаружено позднего появления прогрессирующей тугоухости. Отсутствует связь между развитием слуха и особыми симптомами риска или тимпанометрией.

Выводы: В ходе проанализированной программы не обнаружено прогрессирующей тугоухости или её позднего появления, но обнаружены значительные задержки в развитии слуховых умений в первые два года жизни у детей из отделений интенсивной терапии (NICU) и промежуточного медицинского ухода для новорождённых.

Ключевые слова: аудиология • массовое обследование новорождённых • развитие ребёнка

\section{ROZWÓJ SŁUCHU U DZIECI Z ODDZIAŁÓW INTENSYWNEJ TERAPII I POŚREDNIEJ OPIEKI ZDROWOTNEJ W BRAZYLII}

\section{Streszczenie}

Wprowadzenie: Niezdiagnozowany niedosłuch po narodzeniu może źle wpłynąć na rozwój językowy, społeczny i edukacyjny dziecka. Państwowe i międzynarodowe komisje zajmujące się słuchem noworodków podkreślają znaczenie wczesnego wykrycia niedosłuchu, jego leczenia i wczesnej interwencji. Celem badania była analiza danych dotyczących rozwoju słuchu na podstawie wypisów z oddziałów intensywnej terapii dla noworodków (NICU) oraz z oddziałów pośredniej opieki zdrowotnej w szpitalu dla kobiet im Prof. Dr José Aristodemo Pinotti w brazylijskim stanie Sao Paulo.

Materiał i metody: Jest to badanie retrospektywne bazujące na dokumentacji objętej programem badawczym. Dane pochodzą z dokumentacji zebranej od 2012 do 2015 roku obejmującej 88 pacjentów. Zawierają wyniki behawioralnych badań słuchu, audiometrii VRA (Visual Reinforcement Audiometry) i tympanometrii. Dane zostały poddane analizie opisowej i statystycznej.

Wyniki: Zmiany w rozwoju umiejętności słuchowych w pierwszych dwóch latach życia u dzieci pozostających na oddziałach intensywnej terapii (NICU) i pośredniej opieki zdrowotnej przez ponad 48 godzin były istotne. Jednakże nie zaobserwowano późnego pojawiania się lub postępującego niedosłuchu. Nie ma związku pomiędzy rozwojem słuchu a szczególnymi oznakami ryzyka lub tympanometrią.

Wnioski: Podczas analizowanego programu, nie zauważono postępującego niedosłuchu lub jego późnego pojawienia się, ale zaobserwowano znaczące opóźnienia w rozwoju umiejętności słuchowych w pierwszych dwóch latach życia dzieci z oddziałów intensywnej i pośredniej opieki zdrowotnej dla noworodków.

Słowa kluczowe: audiologia • badania przesiewowe u noworodków • rozwój dziecka

\section{Background}

Unidentified hearing loss at birth can have severe consequences on the linguistic, social, and educational development of children. Thus, the Joint Committee on Infant Hearing (JCIH) stresses early identification and intervention of children with hearing loss based on Neonatal Hearing Screening programs and child hearing health care, advocating that these actions should occur before the infant is one month old [1].

In Brazil, since 1995, the first steps have been taken towards implementing hearing care programs targeting children [2]. Over the years, the proposal has gained strength with Law 12.303 of 2 August 2010 [3], which calls for the implementation of neonatal hearing screening (NHS), which makes it possible to detect early hearing loss, as suggested by JCIH [1].

In recent years, questions about hearing screening in newborns have been the subject of wide discussion, particularly after the establishment of JCIH and the Multidisciplinary Committee on Hearing Care (COMUSA) in 2007, in order to ensure better care for the health of these subjects [1,2]. Since then, a number of overhauls have been carried out, relating mostly to the hearing health care of children.

The last review carried out by JCIH in 2007 suggested the use of different protocols for NHS depending on whether the child is in a normal ward or in a Neonatal Intensive 


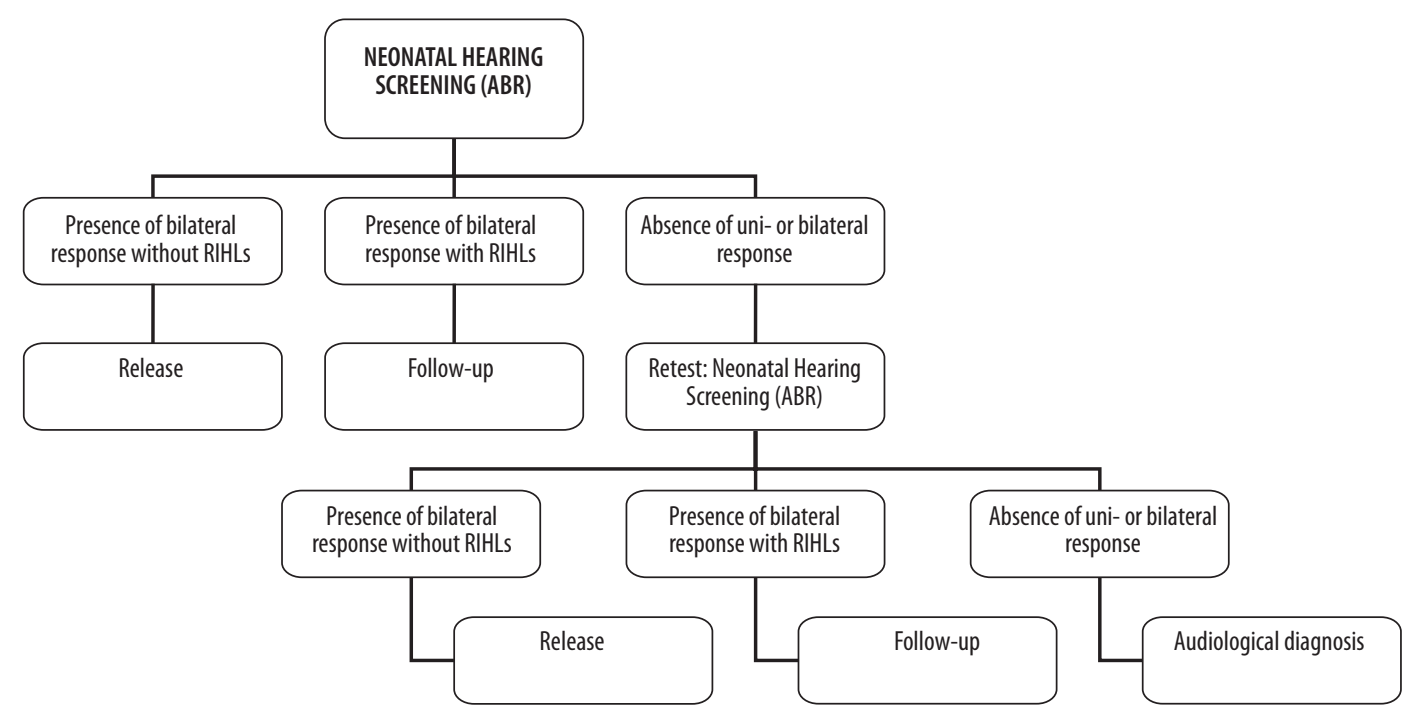

Figure 1. Neonatal Hearing Screening

Care Unit (NICU), as well as the follow-up of cases that present risk indicators for hearing development [1]. The proposal outlined how to carry out follow-ups depending on the presence of the indicators, and providing at least one audiological evaluation in the period up to an age of 24 or 30 months, the aim being to detect or prevent progressive hearing losses or late-onset losses in childhood $[1,2]$.

The risk indicators for hearing loss (RIHLs) proposed by $\mathrm{JCIH}$ in 2007 concern progressive or late-onset hearing losses, highlighting factors such as the concern of a caregiver about the child's development, a family history of permanent hearing loss in childhood, the use of mechanical ventilation, congenital cytomegalovirus infection, syndromes associated with hearing loss, neurodegenerative disorders, postnatal infections related to hearing loss, and chemotherapy [1], for which follow-ups must be done.

Despite improved awareness and implementation of NHS, the follow-up of newborns with RIHLs is still difficult and, in some cases, not possible within several childhood hearing health care services in Brazil. Based on what the Ministry of Health [4] suggests, the service which is held responsible for the execution of NHS must be linked with primary care and/or specialized services which can ensure follow-up of hearing development. However, several studies have already illustrated the difficulties encountered when it comes to interfacing with the healthcare network, as well as a high evasion index of those programs $[5,6]$.

Bearing in mind the desirability of early detection and intervention from NHS, the multiple risks factors associated with late-onset hearing loss in children, and the difficulty of performing follow-ups in newborns, the aim of this study was to look for trends in a follow-up program on hearing development involving exits from the NICU program and from an intermediate care neonatal program.

\section{Material and methods}

This is a retrospective study based on records of a followup program on hearing development provided to an exit population of infants from NICU and neonatal intermediate care wards at Prof. Dr. Jose Aristodemo Pinotti Women's Hospital. The research was developed at the clinical school of a graduate course in Speech, Language and Hearing Sciences within the Brazilian State of Sao Paulo. It was approved by the Ethics and Research Committee (number $1085 / 2009$ ) and complied with the ethical requirements of research on human subjects in terms of Resolution 196/96 of CONEP. The data collection period encompassed records for the years 2012 to 2015 .

The follow-up on hearing development is part of the hearing health care program carried out by the institution, which follows the Neonatal Hearing Screening (NHS) flowchart for audiological diagnosis (Figure 1). The chart suggests that infants with RIHLs be followed every 6 months until they are 2 years old, carrying out a total of four evaluations based on an anamnesis protocol and evaluations standardized by the service (Figure 2). Follow-up evaluations were always performed by postgraduate therapists in Hearing Health Care or by residents of the Multidisciplinary Program on Child and Adolescent Health.

The anamnesis was performed at the first contact with the infant and aimed to collect basic information as well as records of RIHLs. The evaluations were carried out in an acoustically treated room, with the child held on the lap of their caregiver and in the presence of at least two evaluators, one assuming a position in front of the child while the other presented the stimuli.

At an age of 6 months, the follow up comprised a behavioral evaluation, visual reinforcement audiometry, and tympanometry. The behavioral evaluation was performed with non-calibrated sounds: a rattle and a bell being presented laterally to evaluate localization and an agogo bell being used to verify the cochleopalpebral reflex (CPR). Visual reinforcement audiometry was performed with a pediatric audiometer (Interacoustics PA5) at 500, 1000, 2000, and $4000 \mathrm{~Hz}$, with 20 and $80 \mathrm{~dB}$ being the minimum and maximum levels assessed by the device. To obtain responses, stimuli were presented in decreasing order in the right and 


\begin{tabular}{|c|c|c|c|c|}
\hline Stage of evaluation & 6 months & 12 months & 18 months & 24 months \\
\hline Anamnesis & Protocol & & & \\
\hline $\begin{array}{l}\text { Behavioral hearing } \\
\text { evaluation }\end{array}$ & $\begin{array}{l}\text { Lateral location; CPR } \\
\text { present }\end{array}$ & $\begin{array}{l}\text { Indirect location down } \\
\text { and direct up; CPR } \\
\text { present }\end{array}$ & $\begin{array}{l}\text { Direct location down } \\
\text { and up, CPR present }\end{array}$ & $\begin{array}{l}\text { Direct location down } \\
\text { and up, CPR present }\end{array}$ \\
\hline $\begin{array}{l}\text { Visual reinforcement } \\
\text { audiometry }\end{array}$ & $\begin{array}{l}\text { Minimum response level } \\
60 \text { to } 80 \mathrm{~dB}\end{array}$ & $\begin{array}{l}\text { Minimum response level } \\
20 \text { to } 40 \mathrm{~dB}\end{array}$ & $\begin{array}{l}\text { Minimum response level } \\
20 \mathrm{~dB}\end{array}$ & $\begin{array}{l}\text { Minimum response level } \\
20 \mathrm{~dB}\end{array}$ \\
\hline Tympanometry & $\begin{array}{l}\text { Tympanometry curve } \\
\text { type A }\end{array}$ & $\begin{array}{l}\text { Tympanometry curve } \\
\text { type A }\end{array}$ & $\begin{array}{l}\text { Tympanometry curve } \\
\text { type A }\end{array}$ & $\begin{array}{l}\text { Tympanometry curve } \\
\text { type A }\end{array}$ \\
\hline $\begin{array}{l}\text { Response to simple } \\
\text { orders }\end{array}$ & & $\begin{array}{l}\text { Response to simple } \\
\text { orders in voice } \\
\text { presentation }\end{array}$ & $\begin{array}{l}\text { Response to simple } \\
\text { orders in voice } \\
\text { presentation }\end{array}$ & $\begin{array}{l}\text { Response to simple } \\
\text { orders in voice } \\
\text { presentation }\end{array}$ \\
\hline Recognition of figures & & & $\begin{array}{l}\text { Recognition of known } \\
\text { figures }\end{array}$ & $\begin{array}{l}\text { Recognition of known } \\
\text { figures }\end{array}$ \\
\hline
\end{tabular}

Figure 2. Follow-up stages of evaluation (6-24 months) and the criteria on which adequate/inadequate ratings were made

left lateral planes after visual conditioning. Tympanometry was carried out with a tympanometer (Interacoustics MT10) at a frequency of $226 \mathrm{~Hz}$ or with an Otoflex 100 (Otometrics) at $1000 \mathrm{~Hz}$; the ipsilateral reflex was sought at $226 \mathrm{~Hz}$ (up to a maximum of $100 \mathrm{~dB}$ NPS).

In the second evaluation, at 12 months of age, in addition to the aforementioned tests, responses to simple orders given by the evaluator or by the child's caregiver were also recorded; the third and fourth evaluations required the recognition of figures (ball, cat, dog, pacifier, bird, baby bottle, apple, car, banana) visually presented to the child for them to name or identify, based on options provided by the evaluator. The four stages of testing, as well as the expected response parameters, are set out in Figure 2. If any changes were detected in the evaluations, indicating a possible hearing loss, there was the possibility of referral for other tests, such as otoacoustic emissions or otorhinolaryngological testing.

Inclusion of a subject in the research involved satisfying two criteria. 1) Records of the newborn from the NICU, or from the neonatal intermediate care ward, who had been through NHS through Brainstem Evoked Response Audiometry (BERA) with presentation at $35 \mathrm{~dB}$ and bilateral responses, and was referred to the hearing follow-up program because they had risk indicators for the development of hearing loss identified on NHS. 2) Attendance at four evaluations under the program, carried out at ages of $6,12,18$, and 24 months.

The exclusion criteria covered: 1) Records of newborns who, despite having been identified with risk indicators of hearing loss, did not begin or did not finish the followup under the program; 2) Records with incomplete data.

In this way, information on 88 users observed within the aforementioned period was collected. The data analyzed concerned the behavioral hearing test, visual reinforcement audiometry, and tympanometry. These three levels were selected because they were common to all stages.

The data were analyzed in a descriptive way based on parameters already well-established in the literature $[5,7,8]$ and classified as "adequate" or "inadequate". A statistical analysis was done in order to test for the effect of time. A generalized linear model [8] was applied assuming a binomial distribution of responses. Whenever a significant effect of time was found, a multiple comparisons test $[9,10]$ was done, testing the significance of pairs of times. The $p$ values to compare time pairs were adjusted to reflect multiple comparisons. Fisher's exact test was applied for the development of behavioral hearing evaluation when the values in any of the cells of the contingency table was smaller than 5 . The significance level was set at $5 \%(p=0.05)$.

\section{Results}

A total of 88 subjects finished the hearing follow-up program within the studied period; 51 were male and $37 \mathrm{fe-}$ male. For gestational age, 48 were premature and 40 were full-term, with the average gestational age being 35.6 weeks. Regarding weight, 28 newborns were small for their gestational age (SGA), 59 were adequate for their gestational age (AGA), and only 1 was large for gestational age (BGA), with the average weight at birth being $2305 \mathrm{~g}$. The Apgar score in the first minute of life for 26 subjects was equal to or less than 4 , and in the $5^{\text {th }}$ minute less or equal to 6 for 13 subjects.

Results of the behavioral hearing evaluation carried out with three instruments at ages $6,12,18$, and 24 months are shown in Table 1.

In the behavioral hearing evaluation results, there was clear evidence of a time effect, first a immaturity followed by an improvement $(p<0.001)$. For the period from the first set of tests at 6 months to the tests at 12 months, the evaluations changed from adequate $(86.4 \%)$ to mostly inadequate $(81.8 \%)$. Then, from 18 months $(90.9 \%$ inadequate) there was an imaturity, so that at 24 months, the inadequate figure had dropped to $63.2 \%$. The improvement from 6 months to 12 months was statistically significant $(p<0.001)$, and so was the improvement from 18 months to 24 months $(p<0.001)$.

In the visual reinforcement audiometry tests, the aim was to detect any change in the minimum response level expected at each age bracket, since a deterioration suggests 
Table 1. Results of behavioral hearing evaluation on 88 subjects carried out with three instruments at ages of $6,12,18$, and 24 months, with comparisons between the evaluations

\begin{tabular}{|c|c|c|c|c|c|}
\hline \multirow{2}{*}{$\begin{array}{c}\text { Behavioral hearing } \\
\text { evaluation }\end{array}$} & \multicolumn{2}{|c|}{ Adequate } & \multicolumn{2}{|c|}{ Inadequate } & \multirow{2}{*}{$\begin{array}{l}p \text {-value adjusted for multiple } \\
\text { comparisons }\end{array}$} \\
\hline & $\mathbf{N}$ & $\%$ & $\mathbf{N}$ & $\%$ & \\
\hline 6 months & 76 & 86.4 & 12 & 13.6 & \multirow{3}{*}{$\begin{array}{c}6 \times 12 \mathrm{~m} \leq 0.001 \\
12 \times 18 \mathrm{~m}=0.065\end{array}$} \\
\hline 12 months & 16 & 18.2 & 72 & 81.8 & \\
\hline 18 months & 8 & 9.1 & 80 & 90.9 & \\
\hline 24 months* & 32 & 36.8 & 55 & 63.2 & $18 \times 24 m \leq 0.001$ \\
\hline
\end{tabular}

* At this age, one of the subjects did not perform a behavioral hearing evaluation.

Table 2. Results of visual reinforcement audiometry at ages of $6,12,18$, and 24 months

\begin{tabular}{ccccccc}
\hline \multirow{2}{*}{$\begin{array}{c}\text { Visual reinforcement } \\
\text { audiometry }\end{array}$} & \multicolumn{2}{c}{ Inadequate } & \multicolumn{2}{c}{ Adequate } & \multicolumn{2}{c}{ Not evaluated } \\
\cline { 2 - 7 } & $\boldsymbol{N}$ & $\%$ & $\boldsymbol{N}$ & $\%$ & $\boldsymbol{N}$ & $\%$ \\
\hline 6 months & 2 & 2.3 & 78 & 88.6 & 8 & 3.1 \\
\hline 12 months & 0 & 0 & 85 & 96.5 & 3 & 1 \\
\hline 18 months & 4 & 4.5 & 83 & 94.3 & 1 & 1.1 \\
\hline 24 months & 2 & 2.3 & 85 & 96.6 & 1.1 \\
\hline
\end{tabular}

Table 3. Evaluation of 8 cases in which there was a shift in classification (adequate/inadequate) according to visual reinforcement audiometry (using the minimum acceptable response levels listed in Figure 2)

\begin{tabular}{ccccc}
\hline Subject & Stage of evaluation & $\begin{array}{c}\text { Behavioral hearing } \\
\text { evaluation }\end{array}$ & $\begin{array}{c}\text { Visual reinforcement } \\
\text { audiometry }\end{array}$ & $\begin{array}{c}\text { Tympanometry } \\
\text { classification }\end{array}$ \\
\hline 1 & $6 \mathrm{~m}$ & adequate & inadequate & AS \\
\hline 2 & $6 \mathrm{~m}$ & inadequate & inadequate & $\mathrm{A}$ \\
\hline 3 & $18 \mathrm{~m}$ & inadequate & inadequate & $\mathrm{B}$ \\
\hline 4 & $18 \mathrm{~m}$ & inadequate & inadequate & not evaluated \\
\hline 5 & $18 \mathrm{~m}$ & inadequate & inadequate & $\mathrm{AS}$ \\
\hline 7 & $18 \mathrm{~m}$ & inadequate & inadequate & $\mathrm{C}$ \\
\hline 8
\end{tabular}

a hearing loss. In some cases, evaluations were not possible due to the non-conditioning of the child to visual reinforcement. The results of visual reinforcement audiometry for each timeframe are listed in Table 2.

For the visual reinforcement audiometry tests, there was only a small percentage of subjects who had their test classification altered from adequate to inadequate, at least in terms of responses to the minimum parameter levels for each age bracket in Figure 2. Considering only the 8 cases for which a change in classification was found (using the minimum levels of responses in Figure 2), the results are presented in Table 3.

It is important to underline that the changes at the minimum levels of response were not observed in the same subject at different stages. Furthermore, by correlating the findings with tympanometry, it was possible to observe middle ear changes which might suggest that conductive changes of a transitory nature, or even that difficulties in conditioning when performing the tests, interfered with the results. However, when acoustic immittance was analyzed statistically, the correlation between the findings of the tympanometric evaluation and hearing ability was not significant. In this work, Fisher's exact test was applied to each timeframe, and there was no evidence of association (Table 4). The interpretation is that a tympanometric change does not necessarily represent a change in hearing ability.

Finally, the relationship between risk factors (RIHLs) and the result of the behavioral hearing evaluation at 24 months 
Table 4. Relationship between the results of tympanometry and the rating of hearing development observed in the behavioral hearing evaluation

\begin{tabular}{|c|c|c|c|c|}
\hline & \multirow{2}{*}{ Tympanometry } & \multicolumn{2}{|c|}{ Behavioral hearing evaluation rating } & \multirow{2}{*}{$p$-value } \\
\hline & & Adequate & Inadequate & \\
\hline \multirow{2}{*}{ 6-12 months } & normal & 11 & 37 & \multirow{2}{*}{0.723} \\
\hline & altered & 2 & 24 & \\
\hline \multirow{2}{*}{$12-18$ months } & normal & 2 & 36 & \multirow{2}{*}{0.882} \\
\hline & altered & 3 & 27 & \\
\hline \multirow{2}{*}{$18-24$ months } & normal & 19 & 30 & \multirow{2}{*}{0.965} \\
\hline & altered & 10 & 15 & \\
\hline
\end{tabular}

was analyzed. In this analysis, there was no evidence of association ( $p$-values) between the RIHLs and the results of the behavioral hearing evaluation at 24 months (Table 5). This means that the level of hearing development at the end of the 2-year evaluation period is in accordance with levels described in the literature [5-7]. In Table 5 a full statistical analysis was not performed because of the small number of cases.

\section{Discussion}

Hearing follow-ups are recommended by JCIH in cases where RIHLs have been identified. Initially, in a publication of 2000 [12], the JCIH suggested doing follow-ups semiannually, but since then many studies have shown that meeting such a guideline is generally not possible. This is due to several factors, but particularly the difficulties encountered by hearing health care services in coping with the number of evaluations and the frequent losses to follow up which occur during the process $[5,6,13]$.

Mindful of a need for change, in 2007 the JCIH overhauled its guidelines, indicating that infants who had a risk indicator for hearing loss should receive at least one evaluation before the age of 30 months, with hearing health care services asked to perform more long-term follow-ups for identified cases with indicators of progressive or late-onset hearing loss. Based on the results presented here, the number of such evaluations emerging from the Brazilian program are not so many that they cannot be dealt with on a case-by-case basis, so the follow-up services appear adequate to meet the JCIH guidelines [1].

No cases of permanent late-onset or progressive hearing loss were found within the study group, as shown by Tables 1 and 2. However, the observed changes in the minimum response levels evaluated by visual reinforcement audiometry might be related to development delays in hearing abilities. As already pointed out by other studies, there can be major delays in maturation and changes in hearing parameters during development, which are mainly seen by behavioral evaluation [14]. The present data show the complementary nature of information provided by the evaluation, behavioral, and visual reinforcement methods, and it underlines the importance of adopting a battery of tests at follow-up.

The data here show that different trends occurred in the development of hearing between 6 and 24 months. Table 1 shows that between 6 to 12 months there was a immaturity in hearing, but this reversed again between 18 and 24 months. The statistical differences were significant $(p<0.001)$.

As pointed out by a number of authors [14-16], identification of any early change in the auditory system is vital to avoid, or minimize, delayed language and/or learning. From our results, the significance of changes between the ages of 6 and 12 months can be difficult to assess. Sometimes a longer period of time - 18 or 24 months - is needed in order to observe full maturation of the behavioral auditory responses. Before 6 months, a lateral location is expected, and, within 12 months, a more complex response is the norm, with direct location of the stimulus in the inferior plane and indirect location in the superior plane. Comparing results at 6 months and 12 months is therefore difficult, as the criteria for adequate and inadequate will be based on different parameters. Our data indicate an increase in the behavioral hearing evaluations classified as altered at 12 months of age.

Similar considerations relate to comparison between results obtained at 18 months and 24 months. However, in this situation, the expected response criteria for both stages are the same, and the observed increase in the number of tests classified as normal at 24 months, compared to the number at 18 months, indicates a real improvement and maturation of auditory responses.

We did not observe a statistically significant result between evaluations at 12 and 18 months. This seems to indicate that a reliable set of measurements would require an increased number of follow-up evaluations. Based on the results found here, the 18-month evaluation is questionable, since significant results were only seen at 24 months. Nevertheless, it must be acknowledged that evaluations carried out every 6 months have the potential to provide additional reliability and a greater likelihood of catching impairments in hearing.

So far as tympanometric evaluation is concerned, research has shown that any major changes in that measure suggest some sort of underlying hearing impairment, usually involving inadequate responses in the remaining evaluations, particularly behavioral [17]. However, as shown by Table 4 , we did not find any significant statistical relationship between tympanometric evaluation and behavioral responses. 
Table 5. Relationship between RIHLs and observed hearing development at 24 months obtained from behavioral evaluation

\begin{tabular}{|c|c|c|c|c|}
\hline \multirow{2}{*}{ RIHL } & & \multicolumn{2}{|c|}{ Behavioral hearing evaluation rating } & \multirow[t]{2}{*}{$p$-value } \\
\hline & & Adequate & Inadequate & \\
\hline \multirow{2}{*}{ Family history* } & Yes & 1 & 4 & \multirow{2}{*}{0.369} \\
\hline & No & 31 & 51 & \\
\hline \multirow{2}{*}{ Gestational age } & Preterm & 18 & 30 & \multirow{2}{*}{0.169} \\
\hline & Full term & 14 & 25 & \\
\hline \multirow{3}{*}{ Intrauterine growth } & SGA & 9 & 18 & \multirow{3}{*}{0.589} \\
\hline & AGA & 22 & 37 & \\
\hline & BGA & 1 & 0 & \\
\hline \multirow{2}{*}{ Weight below $1500 \mathrm{~g}$} & Yes & 0 & 10 & \multirow{2}{*}{0.410} \\
\hline & No & 32 & 45 & \\
\hline \multirow{2}{*}{ Apgar 0 to 4 in the 1 st minute } & Yes & 9 & 17 & \multirow{2}{*}{0.180} \\
\hline & No & 23 & 37 & \\
\hline \multirow{2}{*}{ Apgar 0 to 6 after 5 minutes } & Yes & 5 & 7 & \multirow{2}{*}{0.350} \\
\hline & No & 28 & 47 & \\
\hline \multirow{2}{*}{ Craniofacial malformation } & Yes & 0 & 2 & \multirow{2}{*}{0.992} \\
\hline & No & 32 & 53 & \\
\hline \multirow{2}{*}{ Intracranial hemorrhage } & Yes & 1 & 2 & \multirow{2}{*}{0.810} \\
\hline & No & 31 & 53 & \\
\hline \multirow{2}{*}{ Hyberbilirubinemia } & Yes & 4 & 4 & \multirow{2}{*}{0.435} \\
\hline & No & 28 & 51 & \\
\hline \multirow{2}{*}{ Meningitis* } & Yes & 0 & 2 & \multirow{2}{*}{0.992} \\
\hline & No & 32 & 53 & \\
\hline \multirow{2}{*}{ Congenital infection* } & Yes & 1 & 2 & \multirow{2}{*}{1.00} \\
\hline & No & 31 & 53 & \\
\hline \multirow{2}{*}{ Asphyxia } & Yes & 9 & 12 & \multirow{2}{*}{0.723} \\
\hline & No & 23 & 43 & \\
\hline \multirow{2}{*}{ Ototoxic drugs } & Yes & 10 & 24 & \\
\hline & No & 22 & 31 & \\
\hline & Yes & 20 & 24 & 0.200 \\
\hline 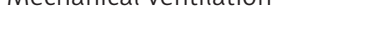 & No & 12 & 31 & \\
\hline & Yes & 5 & 2 & \\
\hline 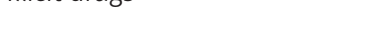 & No & 27 & 53 & \\
\hline & Yes & 1 & 8 & \\
\hline reticute & No & 31 & 47 & 0.113 \\
\hline & Yes & 1 & 2 & \\
\hline & No & 31 & 54 & \\
\hline
\end{tabular}

* RIHL presenting a higher incidence of progressive or late-onset loss 
Turning to risk indicators (Table 5), we saw no correlation between any specific RIHL and changes in hearing and language development at 24 months. We infer that interactions between these multiple factors can lead to a delay in the development of hearing abilities, although no permanent hearing loss was identified. Other studies which have focused on RIHL issues have found similar results. Weichbold et al. [18], in wide-ranging research aiming to see if there was a correlation between RIHLs and postnatal permanent hearing impairment, concluded it was not possible to confidently identify risk indicators requiring a follow-up, or the maximum age at which follow-ups should take place. Beswick [13] found that the most significant RIHLs indicative of late-onset hearing loss were family history, craniofacial deformity, syndromes, and long-term mechanical ventilation.

The JCIH [1] point to the importance of epidemiological studies correlating RIHLs and late-onset hearing loss. The maximum age to which children with RIHLs must be monitored is another issue needing further work.

In this study, the single risk indicator that came closest to predicting a significant change in hearing ability was ototoxic drugs, with $p=0.007$. None of the other indicators mentioned by JCHI [1] as being associated with the occurrence of progressive or late-onset hearing loss produced a significant statistical outcome.

Other authors have also compared the occurrence of RIHLs and the results of behavioral evaluations for calibrated and non-calibrated sounds [5]. Such research has found that, for non-calibrated sounds, there is no significance between the subjects with and without RIHLs; however, for non-calibrated sounds, a significant difference between the groups was noted, with a higher number of inadequate responses for subjects with RIHLs, suggesting a delay in the development of hearing abilities.

Even though this study did not compare children with RIHLs and a control group, the results indicate that major changes in the development of hearing abilities occurred over the first 2 years of life, a finding which concurs with what is found in the literature.

\section{Conclusions}

The results of the data on children from NICU and intermediate care neonatal units have shown that these subjects had no progressive or late-onset losses, but they did show a major delay in the development of hearing abilities in the first 2 years of life.

\section{References:}

1. Joint Committee on Infant Hearing. Year 2007 Position Statement: Principles and guidelines for early hearing detection and intervention programs. Pediatrics, 2007; 120(4): 898-921.

2. Lewis DR, Marone SAM, Mendes BCA, Cruz OLM, Nóbrega M. Multiprofessional Committee on Auditory Health: COMUSA. Braz J Otorhinolaringol, 2010; 76(1): 121-28.

3. Brasil. Presidência da República. Lei no. 12.303. 2010. Available at: http://www.planalto.gov.br/ccivil_03/_ato2007-2010/2010/ lei/l12303.htm. Downloaded 2017/08/25.

4. Ministério da Saúde, Brasil. Secretaria de Atenção à Saúde. Departamento de Ações Programáticas Estratégicas e Departamento de Atenção Especializada. Brasília. 2012. Available at: http://bvsms.saude.gov.br/bvs/publicacoes/diretrizes_atencao_ triagem_auditiva_neonatal.pdf. Downloaded 2017/08/25.

5. Northern JL, Downs MP: Hearing in Children ( $5^{\text {th }}$ ed.), 2002. Williams \& Wilkins, Philadelphia.

6. Nisotakis E, Chalkiadakis V, Marangoudakis P, Tzagkaroulakis A, Nikolopoulos T. Risk factors affecting hearing in neonatal intensive care unit neonates. J Hear Sci, 2016; 6(3): 45-53.

7. Vanhuyse VJ, Creten WL, Van Camp KJ. On the w-notching of tympanograms. Scand Audiol, 1975; 4: 45-50.

8. Nelder J, Wedderburn R. Generalized linear models. J Roy Statist Soc, Series A (General), 1972; 135(3): 370-84.

9. Aickin $M$, Gensler $H$. Adjusting for multiple testing when reporting research results: The Bonferroni vs Holm methods. Am J Public Health, 1996; 86(5): 726-28.

10. Benjamini Y. Simultaneous and selective inference: current successes and future challenges. Biometrical J, 2010; 52(6): 708-21.
12. Year 2000 Position Statement: Principles and guidelines for early hearing detection and intervention programs. Joint Committee on Infant Hearing, American Academy of Audiology, American Academy of Pediatrics, American Speech-HearingLanguage Association, and Directors of Speech and Hearing Programs in State Health and Welfare Agencies. Pediatrics, 2000; 106(4): 798-817.

13. Beswick R, Driscoll C, Kei J, Glennon S. Targeted surveillance for postnatal hearing loss: a program evaluation. Int J Pediatr Otorhinolaryngol, 2012; 76(7): 1046-56.

14. Barreira-Nielsen C, Fitzpatrick E, Hashem S, Whittingham J, Barrowman N, Aglipay M. Progressive hearing loss in early childhood. Ear Hear, 2016; 37(5): e311-21.

15. Tran T. Late newborn hearing screening, late follow-up, and multiple follow-ups increase the risk of incomplete audiologic diagnosis evaluation. J Early Hear Detect Intervention, 2016; 1(2): 49-55.

16. Vohr BR. Language and hearing outcomes of preterm infants. Semin Perinatol, 2016; 40(8): 510-19.

17. Alaerts J, Luts H, Wouters J. Evaluation of middle ear function in young children: Clinical guidelines for the use of 226- and 1,000-Hz tympanometry. Otol Neurotol, 2007; 28(6): 727-32.

18. Weichbold V, Nekahm-Heis D, Welzl-Mueller K. Universal newborn hearing screening and postnatal hearing loss. Pediatrics, 2006; 117(4): 631-36. 